Laporan Penelitian

\title{
Validitas pemeriksaan rapid test immunochromatography berbasis EBV pada penderita karsinoma nasofaring di Makassar
}

\author{
Helen Nazaruddin, Eka Savitri, Muhammad Amsyar Akil, Jane Carolina \\ Bagian Ilmu Kesehatan Telinga Hidung Tenggorok \\ Fakultas kedokteran Universitas Hasanuddin \\ Makassar
}

\begin{abstract}
ABSTRAK
Latar belakang: Karsinoma nasofaring (KNF) adalah tumor ganas yang tumbuh di daerah nasofaring dengan predileksi di fossa Rosenmuller dan atap nasofaring. KNF menunjukkan beberapa gejala awal yang tidak spesifik sehingga seringkali terdiagnosis pada stadium lanjut, dengan angka keberhasilan pengobatan yang lebih rendah dibandingkan jika diobati pada stadium awal. Tujuan: Menilai sensitifitas NPC test strip dibandingkan terhadap ELISA dalam mendeteksi karsinoma nasofaring dan menilai spesifitas NPC test strip dibandingkan terhadap ELISA dalam mendeteksi karsinoma nasofaring. Metode: Penelitian ini merupakan uji diagnostik dengan jumlah sampel sebesar 66 yang terbagi atas 38 pasien KNF dan 28 adalah keluarga dari pasien KNF. Masing-masing sampel diambil darahnya untuk kemudian dilakukan pemeriksaan ELISA dan NPC test strip. Data dianalisis menggunakan tabulasi silang. Hasil: Sensitifitas NPC test strip dibandingkan terhadap ELISA dalam mendeteksi karsinoma nasofaring adalah sebesar $78 \%$, dengan positif palsu sebesar $75 \%$ dan nilai prediksi positif sebesar $76,47 \%$. Spesifitas $N P C$ test strip dibandingkan terhadap ELISA dalam mendeteksi karsinoma nasofaring adalah sebesar 25\%, dengan negatif palsu sebesar $22 \%$ dan nilai prediksi negatif sebesar $26,67 \%$. Kesimpulan: Penggunaan $N P C$ test strip dalam deteksi dini KNF belum dapat direkomendasikan mengingat masih rendahnya sensitifitas dan spesifitas NPC test strip ini.
\end{abstract}

Kata Kunci: Karsinoma nasofaring, ELISA, NPC test strip.

\section{ABSTRACT}

Background: Nasopharyngeal carcinoma (NPC) is a malignant tumor that grows in the nasopharynx with a predilection for the Rosenmuller fossa and the roof of the nasopharynx. NPC shows unspecific early symptoms and is often diagnosed at advanced stages, with treatment success rate lower than if treated at earlier stages. Purpose: To assess the sensitivity of NPC test strip against ELISA in the detection of nasopharyngeal carcinoma and to assess the specificity of NPC test strip against ELISA in the detection of nasopharyngeal carcinoma. Methods: A diagnostic study of 66 samples, consisting of 38 NPC patients and 28 relatives of NPC patients. Each blood sample was taken for Elisa and NPC tests strip. Data were analyzed using cross tabulation. Results: NPC test strip showed sensitivity 78\% compared to ELISA in the detection of nasopharyngeal carcinoma with addition $75 \%$ false positives and positive predictive value of $76,47 \%$. NPC test strip specificity was $25 \%$ compared to ELISA in detecting nasopharyngeal carcinoma, with false negative $22 \%$ and negative predictive value of $26.67 \%$. Conclusion: The use of NPC test strip in early detection of NPC could not be recommended, given the low sensitivity and specificity NPC Test Strip in this study.

Keywords: Nasopharyngeal carcinoma, ELISA, NPC Test Strip

Alamat korespondensi: DR.Dr. Eka Savitri,SpTHT-KL. email: ekasapan@yahoo.com 


\section{PENDAHULUAN}

Karsinoma Nasofaring (KNF) adalah tumor ganas yang tumbuh di daerah nasofaring dengan predileksi di fossa Rosenmuller dan atap nasofaring. KNF merupakan keganasan epitelial yang merupakan neoplasma dengan insiden tersering pada traktus aerodigestif bagian atas, yang distribusinya tersebar di seluruh dunia. ${ }^{1}$ Insidens KNF pada populasi di Asia Tenggara menunjukkan adanya peningkatan yang tinggi, demikian pula di Indonesia yang terlihat dengan adanya peningkatan jumlah kunjungan penderita baru pada dekade terakhir yang dijumpai di poliklinik THT, khususnya di Rumah Sakit Umum Daerah. ${ }^{2}$ Di bagian THT di Indonesia, KNF merupakan peringkat pertama penyakit kanker pada kepala leher dengan perbandingan antara laki-laki dan wanita adalah 2-3:1. Di Yogyakarta, KNF relatif lebih tinggi, mencapai 5,7 per 100.000 populasi. Insidens di Makassar propinsi Sulawesi Selatan, dilaporkan pada RSU Dadi dan RS Dr.Wahidin Sudirohusodo selama periode 10 tahun (1990-1999) ditemukan 274 kasus KNF dari tumor ganas kepala dan leher $(47,98 \%){ }^{3}$ Periode Januari 2004 sampai dengan Juni 2007 didapatkan 33\% dari keganasan di bidang THT. ${ }^{4}$ Dilaporkan pada periode tahun 2000-2009 di RS.Dr.Wahidin Sudirohusodo ditemukan 362 kasus KNF $(57,28 \%)$ dari tumor kepala dan leher. ${ }^{3}$

Hubungan antara EBV dan KNF pertama kali diteliti pada tahun 1996, didapatkan kenaikan serum antibodi terhadap sel yang terinfeksi EBV.Penelitian di beberapa negara mendapatkan data bahwa pada KNF terjadi peningkatan titer imunoglobulin $\mathrm{G}$ ( $\mathrm{IgG}$ ) dan imunoglobulin $\mathrm{A}$ (IgA). Meningkatnya titer IgG terhadap protein EBV merupakan ciri khas KNF. Pemantauan respons antibodi terhadap EBV terbukti sangat bermanfaat untuk diagnosis KNF. Peningkatan titer IgA terhadap early antigen (EA), viral capsid antigen (VCA) dan Epstein-Barr nuclear antigen 1 (EBNA1) yang ditemukan pada pasien KNF dapat digunakan sebagai penanda (marker) diagnosis dan prognosis. Oleh karena itu pemeriksaan serologi menjadi alat bantu unuk menegakkan diagnosis KNF. ${ }^{5}$ Peningkatan VCA dapat terlihat 8-30 bulan sebelum terjadinya KNF sehingga sangat penting untuk skrining dan deteksi dini. ${ }^{6}$

Metode standar diagnosis EBV adalah Immunofluorescence Assay (IFA), tetapi karena metode ini tidak praktis, subyektif dan relatif mahal maka dikembangkan metode ELISA (Enzyme Linked Immunosorbent Assay). Fachiroh et $\mathrm{al}^{7}$ berhasil mengembangkan metode serodiagnosis berbasis ELISA untuk menunjang diagnosis KNF menggunakan kombinasi 2 antigen dalam satu tes yaitu metode sintetik EBNA 1 dan VCA-p18. Meskipun pemeriksaan (EBNA $1+$ VCA-p18) merupakan metode cukup handal, namun masih dijumpai beberapa keterbatasan mengingat Indonesia sebagai negara kepulauan yang belum memiliki kesetaraan standar pelayanan kesehatan yang sama. Aplikasi ELISA hanya dapat dilakukan di laboratorium yang memiliki fasilitas memadai dan perlu waktu beberapa jam untuk mendapatkan hasilnya. Oleh karena itu diperlukan uji cepat (rapid test) dengan metode imunokromatografi berbasis protein early antigen (EA) yang dapat diaplikasikan langsung di lapangan tanpa fasilitas laboratorium, cukup dengan mencelup strip ke dalam sampel. Early antigen (EA) merupakan kompleks yang terdiri dari beberapa macam protein, yaitu DNAase, timidin kinase, major EA (D)-p47/54, EA(D)-p138 dan ZEBRA. Komponen kompleks protein EA selanjutnya diekstraksi dan menggunakan konsentrasi $\mathrm{NaCl}$ bertahap. Dari penelitian sebelumnya, protein kompleks EA ini telah digunakan sebagai antigen pada metode ELISA untuk diagnostik pasien KNF, memberikan hasil sensitifitas $85,7 \%$ dan spesifisitas $94 \% .^{7,8}$

Penggunaan EA dalam pembuatan $N P C$ test strip dimungkinkan karena ukuran molekul kompleks protein ini cukup besar, sehingga dapat diimobilisasi dalam pori-pori membran strip.

Pada penelitian tahun 2009, prototipe NPC test strip telah dikembangkan di laboratorium Fakultas Kedokteran UGM / RSUP Dr Sardjito, Yogyakarta dan diujikan pada 100 penderita NPC dan 60 orang sehat yang memberikan hasil yang menjanjikan, dengan sensitifitas $83 \%$ dan 
spesifisitas $100 \%$. Berdasarkan rumusan diatas maka kami bermaksud mengadakan penelitian tentang validitas NPC test strip pada penderita KNF di Makassar.

Penelitian ini bertujuan menilai sensitifitas dan spesifisitas NPC test strip dibandingkan terhadap ELISA IgA (VCA-p18+EBNA1) dalam mendeteksi karsinoma nasofaring.

\section{METODE}

Penelitian ini merupakan penelitian analitik terhadap uji diagnostik untuk menentukan sensitifitas dan spesifisitas NPC test strip. Penelitian dilaksanakan di RSUP Dr Wahidin Sudirohusodo Makassar selama periode waktu tahun 2011.Populasi penelitian adalah pasien yang terdiagnosis KNF yang datang berobat ke poliklinik THT RSUP Dr Wahidin Sudirohusodo tahun 2011 atau sampai jumlah sampel mencukupi .Sampel adalah seluruh populasi terjangkau yang memenuhi kriteria penelitian dan sampel penelitian diambil dari populasi penelitian yang telah teridentifikasi dan memenuhi kriteria. Pada penelitian uji diagnostik ini diharapkan representatif keterwakilan sampel sebesar 2\%. Dengan demikian dibutuhkan sekitar 60 sampel. Kriteria inklusi pada penelitian ini adalah bersedia ikut dalam penelitian, pasien terdiagnosis KNF menurut kriteria WHO 1979 dan keluarga pasien KNF. Kriteria eksklusi adalah penderita tidak kooperatif, dijumpai keganasan lain selain KNF. Sampel kemudian menjalani anamnesis dan pemeriksaan THT meliputi otoskopi, rinoskopi anterior, rinoskopi posterior, faringoskopi dan nasoendoskopi. Sampel menandatangani informed consent.

Untuk pemeriksaan NPC strip test, diambil darah vena sebanyak $5 \mathrm{cc}$, serum diambil dan dimasukkan ke dalam tabung. Serum tersebut diencerkan dengan dicampur larutan yang disediakan pada kit.NPC strip, ditunggu selama 3-5 menit, kemudian dibaca. Hasil dinyatakan positif jika muncul satu garis warna merah pada strip dan negatif jika tidak muncul garis warna merah pada strip.
Pemeriksaan ELISA IgA (VCA-p18+EBNA 1) dilakukan dengan mencampur antigen dengan p18 di plate, kemudian diinkubasi pada suhu $4^{\circ} \mathrm{C}$ atau $37^{\circ} \mathrm{C}$ selama 2 jam. Supernatan dibuang, tambahkan 3\% BSA (dibuat dalam 1x PBS), diinkubasi 1 jam $37^{\circ} \mathrm{C}$. Supernatan dibuang kemudian tambahkan PBS Tween 0,05\% (dilakukan 4 kali). Tambahkan Mouse anti-human $\operatorname{IgA-HRP}$, diinkubasi 1 jam $37^{\circ} \mathrm{C}$. Supernatan dibuang kemudian tambahkan PBS Tween 0,05\% (dilakukan 4 kali). Tambahkan $100 \mu 1$ TMB ke masing-masing well, inkubasi 30 menit dalam ruangan gelap. Tambahkan $100 \mu 10,5 \mathrm{M} \mathrm{H}_{2} \mathrm{SO}_{4}$ ke masing-masing well. Hasil dibaca pada panjang gelombang $450 \mathrm{~nm}$.

\section{HASIL PENELITIAN}

Penelitian ini dilakukan pada 38 penderita terdiri dari 25 laki-laki (66\%) dan 13 perempuan (34\%), yang datang berobat ke poliklinik THT RSWS, dan 28 sampel sebagai kelompok kontrol terdiri dari 13 laki-laki (46\%) dan 15 perempuan (54\%) yang berasal dari keluarga penderita sesuai kriteria inklusi dan eksklusi. Penelitian ini tidak membedakan jenis kelamin, terbanyak pada sampel penelitian adalah laki-laki (57,6 $\%$ ), dengan rasio perbandingan laki-laki dan perempuan adalah 1,4:1.

Dari 66 sampel penelitian ini, distribusi umur terbanyak pada kelompok penderita KNF terdapat pada kelompok umur antara 3145 tahun sebanyak 16 penderita, dengan rerata umur sampel pada kelompok ini adalah 43 tahun. Distribusi umur terbanyak pada kelompok kontrol terdapat pada kelompok umur antara 1830 tahun sebanyak 23 orang dengan rerata umur sampel pada kelompok ini adalah 26 tahun.

Dari hasil pemeriksaan histopatologi pada sampel penderita KNF diperoleh distribusi penderita KNF berdasarkan gambaran histopatologi menurut WHO 1979 didapatkan terbanyak adalah WHO tipe III yaitu 24 orang $(63,2 \%)$, selanjutnya WHO tipe II sebanyak 13 orang $(34,2 \%)$, dan WHO tipe I ditemukan 1 orang $(2,6 \%)$. 
Untuk gambaran distribusi penderita KNF berdasarkan stadium yang diderita menurut TNM-UICC 2002 terbanyak didapatkan adalah penderita KNF dengan stadium IV yakni sebanyak 18 orang $(47,4 \%)$, selanjutnya penderita KNF stadium III yakni sebanyak 15 orang $(39,5 \%)$, dan penderita KNF stadium II sebanyak 5 orang $(13,2 \%)$,

Dalam penelitian ini dilakukan dua kali pemeriksaan pada setiap sampel, yakni pemeriksaan kadar IgA (VCA-p18+EBNA1) dengan metode ELISA dan yang kedua dilakukan pemeriksaan dengan metode NPC test strip. Pemeriksaan kadar IgA (VCA-p18+EBNA1) dengan metode ELISA pada 38 penderita KNF dan 28 kontrol dilakukan sebagai pembanding sensitifitas dan spesifitas pemeriksaan dengan metode NPC test strip.

Hasil pemeriksaan dengan metode ELISA IgA (VCA-p18+EBNA1) menunjukkan bahwa seluruh sampel pada kelompok penderita KNF memperoleh hasil positif, sedangkan sampel pada kelompok kontrol yang merupakan keluarga penderita KNF sebanyak 12 sampel $(42,9 \%)$ dinyatakan positif, sisanya sebanyak 16 sampel $(57,1 \%)$ dinyatakan negatif.
Hasil pemeriksaan dengan metode $N P C$ test strip memperlihatkan bahwa dari 38 sampel pada kelompok penderita KNF dinyatakan positif sebanyak 28 orang sampel $(73,7 \%)$ dan sisanya 10 orang sampel $(26,3 \%)$ dinyatakan negatif, sedangkan sampel pada kelompok kontrol yang merupakan keluarga penderita KNF sebanyak 23 sampel $(82,1 \%)$ dinyatakan positif, sisanya sebanyak 5 sampel $(17,9 \%)$ dinyatakan negatif.

Setiap penilaian uji diagnostik untuk menentukan sensitifitas dan spesifitias akan memberi empat kemungkinan yaitu hasil positif, positif palsu, negatif palsu dan negatif. Dalam penelitian ini, hasil uji diagnostik dari keempat kemungkinan tersebut disusun dalam tabulasi silang berbentuk tabel $2 \times 2$, dimana hasilnya dinyatakan positif apabila kedua hasil pemeriksaan baik metode ELISA maupun NPC test strip menunjukkan hasil positif, dinyatakan positif palsu jika hasil test ELISA positif tetapi hasil NPC test strip negatif, dinyatakan negatif palsu jika hasil test ELISA negatif tetapi hasil $N P C$ test strip positif, dan dinyatakan negatif jika kedua hasil test baik ELISA maupun NPC test strip menunjukkan hasil negatif.

Tabel 1. Hasil pemeriksaan dengan metode ELISA IgA (VCA-p18+EBNA1)

\begin{tabular}{ccccccc}
\hline $\begin{array}{c}\text { Pemeriksaan } \\
\text { ELISA IgA } \\
\text { (VCA-p18+EBNA1) }\end{array}$ & $\mathbf{n}$ & $\mathbf{\%}$ & $\mathbf{n}$ & $\mathbf{\%}$ & $\mathbf{n}$ & $\mathbf{\%}$ \\
\hline Positif & 38 & 100 & 12 & 42,9 & 50 & 75,8 \\
Negatif & 0 & 0 & 16 & 57,1 & 16 & 24,2 \\
Jumlah & 38 & 100 & 28 & 100 & 66 & 100 \\
\hline
\end{tabular}

Tabel 2. Hasil pemeriksaan dengan metode NPC Test Strip.

\begin{tabular}{ccccccc}
\hline $\begin{array}{c}\text { Pemeriksaan } \\
\text { NPC Test } \\
\text { Strip }\end{array}$ & n & \% & n & Kontrol & N & Total \\
\hline Positif & 28 & 73,7 & 23 & 82,1 & 51 & 77,3 \\
Negatif & 10 & 26,3 & 5 & 17,9 & 15 & 22,7 \\
Jumlah & 38 & 100 & 28 & 100 & 66 & 100 \\
\hline
\end{tabular}


Tabel 3. Analisis sensitifitas dan spesifitas NPC Test Strip.

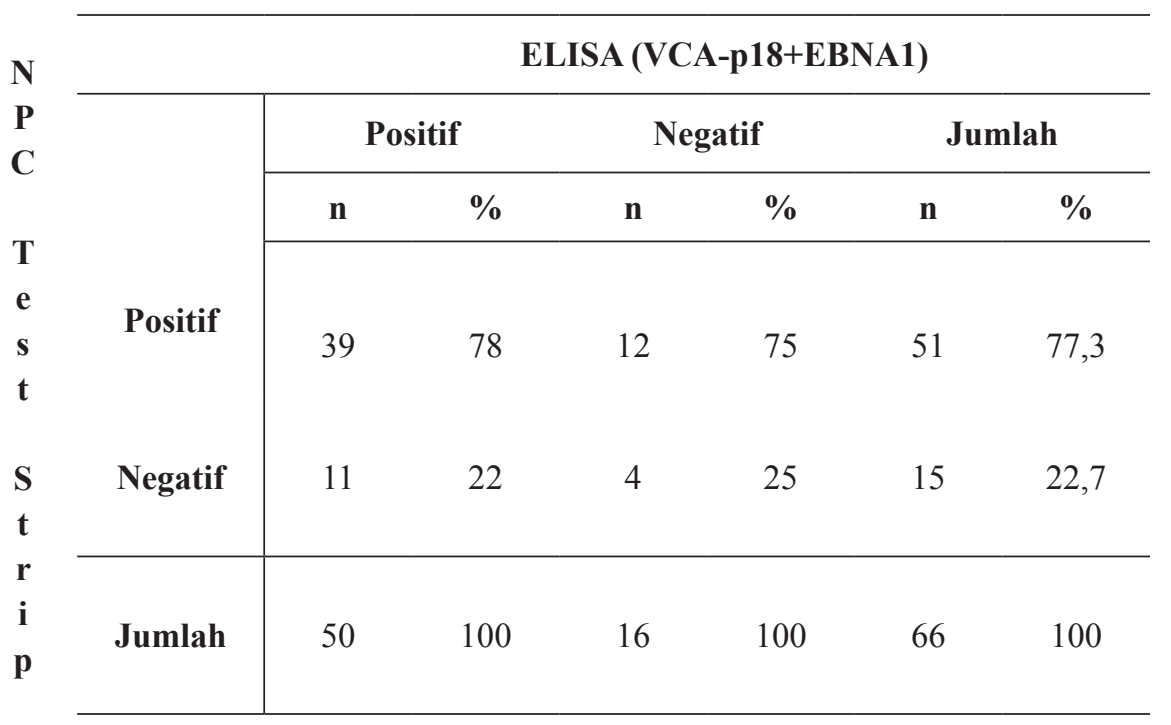

Hasil mendapatkan sensitifitas NPC test strip sebesar $78 \%$ dan spesifitasnya sebesar $25 \%$ terhadap pembanding ELISA. Pada penelitian ini didapatkan hasil positif palsu cukup tinggi yaitu sebesar $75 \%$ dan negatif palsu sebesar $22 \%$. Sedangkan untuk nilai prediksi positif sebesar $77,3 \%$ dan nilai prediksi negatif sebesar $22,7 \%$.

\section{DISKUSI}

Penggunaan metode ELISA IgA (VCAp18+EBNA1) sebagai baku emas untuk menentukan nilai sensitifitas dan spesifitas $N P C$ test strip dalam mendeteksi KNF dalam penelitian ini merupakan pemeriksaan IgA menggunakan kombinasi dua antigen berasal dari peptida sintetik protein EBNA1 dan VCA-p18 yang dalam penelitian ini dilakukan pada 66 sampel terdiri atas 38 sampel yang merupakan penderita KNF dan 28 sampel merupakan keluarga penderita KNF. Dalam kepustakaan disebutkan bahwa insiden risiko terjadinya KNF pada keluarga penderita KNF cukup tinggi yakni 6 kali lebih tinggi dari populasi umum pada generasi pertama. ${ }^{9}$

Jumlah sampel yang memenuhi kriteria inklusi sebanyak 66 sampel terdiri atas 38 sampel (57,6\%) laki-laki dan 28 sampel $(42,4 \%)$ perempuan dengan rasio perbandingan perempuan dan laki-laki adalah1:1,4. Hasil ini tidak jauh berbeda dengan penelitian yang dilakukan oleh
Soewito di RS Wahidin Sudirohusodo yang melaporkan rasio perbandingan perempuan dan laki-laki penderita KNF adalah 1:1,3. ${ }^{10}$ Namun hasil ini berbeda dengan penelitian sebelumnya yang dilakukan oleh Wai yang melaporkan rasio perbandingan perempuan dan laki-laki sebesar 0,8:1. ${ }^{11} \mathrm{Hal}$ ini bisa terjadi karena jumlah sampel dalam penelitian ini masih kecil dibandingkan dengan penelitian sebelumnya.

Berdasarkan karakteristik sampel, rata-rata usia sampel dari 38 penderita KNF adalah 43 tahun dan usia rata-rata sampel dari 28 keluarga penderita KNF adalah 26 tahun, hasil ini sedikit berbeda dengan penelitian terdahulu dimana usia penderita dan keluarga penderita KNF rata-rata 32 tahun. $^{10}$

Distribusi penderita KNF berdasarkan gambaran histopatologi menurut WHO 1979 didapatkan terbanyak adalah WHO tipe III yaitu 24 orang $(63,2 \%)$, selanjutnya WHO tipe II sebanyak 13 orang $(34,2 \%)$, dan WHO tipe I ditemukan 1 orang $(2,6 \%)$, hal ini sesuai dengan yang dilaporkan oleh Savitri, ${ }^{5}$ namun sedikit berbeda dengan yang dilaporkan oleh Soewito ${ }^{10}$ dan Fransiska ${ }^{12}$ yang tidak menemukan WHO tipe I, namun demikian WHO tipe III tetap merupakan yang terbanyak. Histopatologi WHO tipe II dan III hampir 100\% berhubungan dengan infeksi virus Epstein-Barr. 
Distribusi penderita KNF berdasarkan stadium yang diderita menurut TNM-UICC 2002 dalam penelitian ini terbanyak didapatkan adalah penderita KNF dengan stadium IV yakni sebanyak 18 orang $(47,4 \%)$, selanjutnya penderita KNF stadium III yakni sebanyak 15 orang $(39,5 \%)$, dan penderita KNF stadium II sebanyak 5 orang $(13,2 \%)$, hasil ini tidak jauh berbeda dengan penelitian sebelumnya yang dilakukan oleh Perkasa, ${ }^{13}$ Punagi ${ }^{14}$ dan Savitri. ${ }^{5}$ Berbeda dengan Tan Eng- Lai ${ }^{15}$ dari 78 sampel nasofaring stadium I 5 orang, Stadium II 31 orang, stadium III 15 orang, stadium IV 39 orang. Hal ini menandakan bahwa hampir sebagian besar penderita berobat dalam kondisi stadium lanjut, yang menyebabkan prognosis pengobatan dan harapan hidup menjadi berkurang, dimana keberhasilan terapi pasien KNF stadium I dan II lebih dari $80 \%$ keberhasilannya dibandingkan dengan stadium III dan IV yang kurang dari $40 \%$ keberhasilannya. Dengan demikian upaya deteksi dini KNF sangat diperlukan yang salah satunya dapat dilakukan dengan menggunakan metode ELISA maupun NPC test strip. ${ }^{16}$

Hasil pemeriksaan dengan metode ELISA IgA (VCA-p18+EBNA1) dalam penelitian ini pada 38 sampel penderita KNF, mendapatkan hasil seluruh sampel $(100 \%)$ penderita KNF memperoleh hasil positif, sedangkan 28 sampel kontrol yang merupakan keluarga penderita KNF didapatkan hasil 12 sampel (42,9\%) dinyatakan positif, sisanya sebanyak 16 sampel $(57,1 \%)$ dinyatakan negatif. Hasil ini hampir sama dengan penelitian sebelumnya yang melaporkan hasil pemeriksaan kadar IgA secara ELA1) didapatkan hasil positif sebanyak 91,4\% dan pada sampel kontrol didapatkan hasil positif sebanyak $66,7 \% .^{10}$

Pada penelitian ini ditemukan sensitifitas NPC test strip terhadap pembanding ELISA IgA (VCA-p18+EBNA1) sebesar 78\% dan spesifitasnya sebesar $25 \%$. Hal ini menunjukkan bahwa kemampuan NPC test strip dalam mendeteksi KNF lebih besar dibanding kemampuannya dalam menentukan subyek tidak menderita KNF yakni 78 berbanding 25, namun hasil ini belum memadai mengingat hanya $78 \%$ di antara subyek penderita KNF yang dapat dideteksi dengan NPC test strip ini. Demikian pula dengan spesifitasnya, dimana hanya $25 \%$ ketepatannya dalam mendeteksi subyek yang bukan penderita KNF.

Pada penelitian ini pula didapatkan hasil positif palsu cukup tinggi yaitu sebesar $75 \%$ dan negatif palsu sebesar $22 \%$, sedangkan untuk nilai prediksi positif sebesar $76,47 \%$ dan nilai prediksi negatif sebesar $26,67 \%$. Besarnya positif palsu dan juga rendahnya spesifitas ini kemungkinan disebabkan oleh faktor temporal dalam uji validitas ini. Kelompok kontrol adalah kelompok yang secara klinis dinyatakan tidak menderita tetapi diambil di kalangan keluarga dalam satu garis seketurunan dengan penderita (anak kandung, saudara kandung, orangtua kandung) yang mungkin saja sudah terinfeksi EBV dengan diaktifkannya sinyal transduser dan transkripsi akibat infeksi EBV yang mencapai ambang terukur positif oleh NPC test strip walau masih negatif dalam pemeriksaan VCAp18+EBNA1 dan dinyatakan belum ada keluhan secara klinis.

Dari hasil pemeriksaan ditemukan 8 dari tiap 10 sampel yang positip dengan VCAp18+EBNA1 dinyatakan positif pula oleh $N P C$ test strip. Ada 8 setiap 10 sampel yang dinyatakan negatif oleh VCA-p18+EBNA1 ternyata dinyatakan positif oleh NPC test strip (lihat proporsi positif palsu sebesar 75\%) dan hanya 2-3 tiap 10 sampel yang dinyatakan negatif oleh VCA-p18+EBNA1 juga dinyatakan negatif oleh NPC test strip. Berbeda dengan studi Yogyakarta yang memperoleh sensitifitas $83 \%$ dan spesifisitas $100 \%$. Viral Load yang sangat tinggi ditemukan di Makassar sehingga imunoglobulin tidak mampu, timbul imun sistem anergi. ${ }^{5}$ Besarnya positif palsu serta rendahnya spesifitas memberikan kesimpulan bahwa validitas NPC test strip adalah rendah.

Penelitian pada populasi beresiko dan keluarganya di Makassar ini bertujuan untuk 
mendapatkan informasi gambaran respon titer antibodi menggunakan ELISA IgA (EBNA1+VCA-p18) dan NPC test-strip berbasis pemeriksaan $\operatorname{IgG}$ dan $\operatorname{IgA}$ terhadap EA pada penderita KNF, dan menguji sensitivitas dan spesifisitas prototipe ELISA Ig A (EBNA1+VCA-p18) dan NPC test-strip (penelitian ini merupakan penelitian multisentra di Yogyakarta, Semarang, Malang dan Makassar).

Pada studi sebelumnya pemeriksaan ELISA Ig A (EBNA1+VCA-p18) dan NPC test-strip telah terbukti memiliki sensitivitas berturutturut $85,4 \%$ dan $83 \%$ dan spesifisitas $90,1 \%$ dan $100 \%{ }^{7}$

Pada penelitian yang mewakili 3 daerah yang berbeda di Indonesia ini, titer IgA pada kelompok KNF lebih meningkat dibandingkan dengan titer IgA kelompok kontrol. Titer IgA dari kelompok KNF dan kontrol dari panel Makassar dan Semarang menunjukkan titer yang lebih tinggi dibandingkan titer IgA dari panel Yogyakarta. Hal ini sangat menarik karena pemeriksaan IgA dari daerah yang berbeda menunjukkan pola reaktifitas yg berbeda.Di Makassar reaktifitas IgA pasien KNF dan suspek KNF yang meningkat didapatkan kecenderungan reaktifitas IgA yang meningkat pada keluarganya. Oleh karena itu studi mengenai pola transmisi EBV pada orangorang terdekat (contohnya keluarga), interaksi EBV-pejamu, dan studi genetik populasi EBV dan pejamu perlu dilakukan di Makassar.

Dari penelitian mengenai sensitifitas dan spesifitas NPC test strip terhadap uji IgA Metode ELISA dalam mendeteksi KNF serta dari hasil penelitian dapat dibuat kesimpulan bahwa sensitifitas NPC test strip terhadap ELISA dalam mendeteksi karsinoma nasofaring sebesar $78 \%$. Disamping itu positif palsu sebesar $75 \%$ dan nilai prediksi positif sebesar $76,47 \%$. Sedangkan spesifitas NPC test strip terhadap ELISA dalam mendeteksi karsinoma nasofaring sebesar $25 \%$. Untuk Negatif palsu sebesar 22\% dan prediksi negatif sebesar 26,67\%. Keterbatasaan penelitian ini terletak pada sedikitnya sampel yang didapatkan, oleh karena itu diperlukan penelitian lebih lanjut secara longitudinal dengan sampel yang lebih besar dan seluruh daerah di Indonesia guna mendapatkan hasil yang lebih baik. Diperlukan penelitian cut off Viral Load, mapping genotyping EBV untuk Makassar, dan perlu evaluasi kadar/kepekatan pada strip test yang dapat disesuaikan dengan viral load yang tinggi.

\section{DAFTAR PUSTAKA}

1. Cheng H. Nasopharyngeal cancer and the southeast Asian patient. Am Fam Phys 2001; 63:1776-82.

2. Susworo R. Kanker Nasofaring Epidemiologi dan Pengobatan Mutakhir. Cermin Dunia Kedokteran 2004; 144:16-18.

3. Kuhuwael FG. Bastiana. Perbandingan Kasus Kanker Kepala Leher dalam Dua Dekade di Makassar. Konas PERHATI XV Makassar 2010.

4. Punagi AQ, Savitri E. Profil Karsinoma Nasofaring di Rumah Sakit Pendidikan FK- UNHAS Periode Januari 2004-Juni 2007. Bagian THT-FKUH, 2007:1-5

5. Savitri Eka. Ekspresi Interleukin-8, Interleukin-10 dan Viral Load Epstein-Barr sebagai Indikator Prognostik Pada Kanker Nasofaring. Disertasi Progam Doktor. FK-UNHAS 2009.

6. Zeng Y, Zhang LG, Wu YC, Huang YS, Huang NQ, Li JY, et al. Prospective studies on nasopharyngeal in Epstein -Barr virrus IgA/VCA antibody-positive persons in Wuzhou City, China. Int J Cancer 1985; 36:545-7.

7. Fachiroh J, Paramita DK, Harywiyanto B, A. Harijadi, HL Dahlia, SR Indrasari, et al. Single-Assay combination of Epstein-Barr virus (EBV) EBNA1 and viral capsid antigen-p18-derived syntethic peptides for measuring Anti-EBV immunoglobulin G ( $\mathrm{IgG}$ ) and IgA antibody levels in sera from nasopharyngeal carcinoma patients: options for field screening. J Clin Micr 2006: April:1459-1467.

8. Paramita DK, Fachiroh J, Artama W, Benthem EV, Haryana S, Middeldrop J. Native early antigen of Epstein-Barr virus, a promising antigen for diagnosis of nasopharyngeal carcinoma, J Med Virol 2007; 79:1710-21

9. Zhang F, Zhang J. Clinical hereditary characteristics in nasopharyngeal carcinoma through Ye-Liang's family cluster. Chin Med J (Engl) 1999; 112(2):185-7.

10. Soewito MY. Respon Antibodi IgA (VCAp18+EBNA1) terhadap Eptein Barr Virus (EBV) pada 
keluarga penderita kanker Nasofaring di Makassar. Karya Akhir PPDS THT FK-UNHAS 2009.

11. Wai, Tong Ng, Tsz KY, Yung RWH. Screening for family members of patients with nasopharyngeal carcinoma. Int J Cancer 2005; 113:998-1001.

12. Fransiska TBA. Akurasi hasil pemeriksaan biopsi jarum halus secara endoskopik tersangka karsinoma nasofaring. Karya Akhir PPDS FK-UNHAS 2004.

13. Perkasa MF. Akurasi hasil pemeriksaan "brush biopsy" secara endoskopik pada tersangka karsinoma nasofaring. Karya Akhir PPDS THT FK-UNHAS 2005.
14. Punagi AQ. Analisis polimorfisme gen VEGF pada gambaran klinis dan histopatogi karsinoma nasofaring. Disertasi Program Doktor FK-UNHAS, 2008.

15. Tan Eng-Lai, Selvaratnam G, Kananathan R, Sam Choon-Kook. Quantification of epstein barr virus DNA load, interleukin-10, transforming growth factor- $\beta 1$ and steam cell factor in plasma of patients with nasopharyngeal carcinoma. BioMed Cancer 2006; 24:6-22

16. Tay WL, Tan PH, Yip GWC. Nasopharyngeal carcinoma: an enigmatic tumor ARBS. Annu Rev Biomed Sci 2008; 10:27-35. 